\title{
The role of ICP monitoring in meningitis
}

\author{
Areej Tariq, MBBS, ${ }^{1}$ Pedro Aguilar-Salinas, MD, ${ }^{2}$ Ricardo A. Hanel, MD, PhD, ${ }^{2}$ Neeraj Naval, MD, ${ }^{2}$ \\ and Mohamad Chmayssani, MD2
}

\begin{abstract}
'Department of Neurology, Division of Cerebrovascular Disease and Neurocritical Care, The Ohio State University, Columbus, Ohio; and 2Lyerly Neurosurgery, Baptist Neurological Institute, Jacksonville, Florida
\end{abstract}

\begin{abstract}
Intracranial pressure (ICP) monitoring has been widely accepted in the management of traumatic brain injury. However, its use in other pathologies that affect ICP has not been advocated as strongly, especially in CNS infections. Despite the most aggressive and novel antimicrobial therapies for meningitis, the mortality rate associated with this disease is far from satisfactory. Although intracranial hypertension and subsequent death have long been known to complicate meningitis, no specific guidelines targeting ICP monitoring are available. A review of the literature was performed to understand the pathophysiology of elevated ICP in meningitis, diagnostic challenges, and clinical outcomes in the use of ICP monitoring.
\end{abstract}

https://thejns.org/doi/abs/10.3171/2017.8.FOCUS17419

KEY WORDS meningitis; intracranial pressure; cerebrospinal fluid; critical care

$\mathrm{T}$ HE role of intracranial pressure (ICP) monitoring has been broadly studied and accepted in the setting of traumatic brain injury. ${ }^{5}$ However, its use in other neurological conditions affecting the ICP is limited, especially when managing infections of the CNS. Before the advent of antimicrobial agents, bacterial meningitis was almost exclusively a fatal disease, with a case fatality rate (CFR) greater than $70 \% .{ }^{33}$ The use of antimicrobial agents has markedly reduced mortality rates. However, despite advances in antimicrobial therapy and neurocritical practices, population-based surveillance by the US Centers for Disease Control and Prevention between 1998 and 2007 placed the decline in CFR for bacterial meningitis at a statistically insignificant $1.4 \%(p=0.50){ }^{48}$ Neurological complications account for the major cause of morbidity and mortality in this subset of patients. Death is usually caused by brain tissue infarction secondary to herniation and brainstem compression, septic shock, and coagulation disturbances. ${ }^{7,46,51}$ Certain aspects of the disease, such as intracranial hypertension, ${ }^{4,6,17,18,29}$ have been overlooked during the monitoring of these patients, contributing to the high CFR. Improvement in clinical outcomes cannot be achieved by exclusively using new antimicrobial agents, but instead from novel management modalities based on a more complete understanding of the disease process. Standard management of severe meningitis, especially with stupor and coma (Glasgow Coma Scale [GCS] score $\leq 8$ ), rarely includes invasive measurement of ICP. To date, no guidelines exist regarding the use of ICP monitoring in this disease. Elevated ICP has been shown to be a poor prognostic indicator in meningitis, which suggests that ICP monitoring should be considered as an adjunct to therapy for patients. ${ }^{21}$

Given the paradigm shift in acute neurology in the last decade along with the development of neurointensive care units, ICP monitoring should be considered in addition to the standard therapy of antibiotics and steroids. The purpose of this paper is to present a narrative review of the literature in an effort to better understand the pathophysiology of elevated ICP as well as the clinical impact of monitoring ICP in adults with infectious meningitis.

\section{Pathophysiology}

Intracranial pressure is maintained in a delicate bal- 
ance by limiting forces exerted by the bony skull and the opposing forces by intracranial contents, i.e., brain tissue, CSF, and cerebral blood. Normal values of ICP range between 5 and $15 \mathrm{~mm} \mathrm{Hg}$. Overall, an increase of the ICP may reduce the cerebral perfusion pressure $(\mathrm{CPP}=$ mean arterial pressure - ICP) leading to brain ischemia and infarction if not corrected in a timely manner. Pathogens reach the subarachnoid space (SAS) through the bloodstream or from contiguous sites (spread of infections) and penetrate the blood-brain barrier (BBB) through complex molecular and cellular mechanisms. Meningitis causes an imbalance between the water content of the brain parenchyma, CSF volume, and cerebral blood flow (CBF), resulting in an increase of ICP. ${ }^{36,38}$ Cerebral edema caused by inflammation as well as arterial dilation due to loss of autoregulation and CSF outflow impairment in the SAS are all integral factors in meningitis associated with intracranial hypertension (Fig. 1). Additionally, thrombosis of the cerebral sinuses has been implicated in elevated ICP in both bacterial and viral infections. ${ }^{14,43}$

\section{Inflammation and BBB Disruption}

Bacteria and bacteria cell wall products have been shown to cause a quantitative increase in the water content of the brain in experimental animals with meningitis. ${ }^{47}$ Although the pattern of injury in viral meningitis is believed to be similar, it differs with respect to the degree of parenchymal involment. ${ }^{10,13,18,35}$ Brain edema is shown to be a multifactorial process with cytotoxic, vasogenic, and interstitial forms contributing collectively toward raising the ICP (Fig. 1). Neutrophils that cross into the CSF from the bloodstream in response to inoculation release inflammatory cytokines (tumor necrosis factor [TNF], interleukin [IL]-1 $\beta$, IL-6, IL-8), further stimulating the release of toxic oxygen metabolites as well as vasoactive lipid autacoids such as platelet activating factor, leukotrienes, and prostaglandins (PGs). ${ }^{36,43}$ A disruption in intercellular tight junctions in the cerebral microvessel endothelium occurs in response to these agents, resulting in damage to the BBB. This damage leads to a dramatic paracellular leakage of albumin and eventually vasogenic brain edema. These findings have been reported to be similar in the different types of bacterial meningitis (Streptococcus pneumoniae, Haemophilus influenzae, and Escherichia coli) in rat models. ${ }^{36,37,40}$ Certain viral meningoencephalitis infections have a more complex mechanism of edema that stems from brainstem involvement (rhombencephalitis). For instance, autopsy studies on patients' brains with Nippah Valley encephalitis revealed disseminated microinfarctions secondary to vasculitis hemorrhage, suggesting a possible mechanism of elevated ICP. ${ }^{14}$

\section{Loss of Autoregulation}

The physiology of autoregulation is vaguely understood at the molecular level because of the complex phenomena regulating microvascular blood flow. The autoregulatory caliber changes in cerebral vessels are believed to be mediated by myogenic and metabolic mechanisms, which prevent small changes in systemic arterial pressure to affect the regional CBF. It has been previously shown that this regulatory mechanism is impaired in patients with meningitis. ${ }^{27,30,31,34,47}$ Factors implicated in loss of autoregulation are inflammatory chemicals, reactive oxygen radicals, and disturbances in the balance of vasoactive agents such as PGs and nitric oxide (NO). For example, in a study that compared rats inoculated with $S$. pneumoniae or saline intracisternally, it was observed that autoregulation was disturbed as early as within 12 hours in all the infected samples. ${ }^{30}$ This finding preceded the elevation in ICP by a few hours. Similar results were demonstrated in newborn piglets following inoculation of Group B Streptococci, resulting in impairment of the $\mathrm{CBF}$ autoregulation by means of upregulation of the NO synthase gene. ${ }^{26}$ Another study revealed a progressive increase in $\mathrm{CBF}$ and ICP at 1 and 6 hours after pneumococcal inoculation..$^{34}$ It is speculated that autoregulation is affected primarily by inflammatory cytokines, cyclooxygenase (COX)-derived vasoactive agents (PGs D2, E2, G2, and I2), TNF- $\alpha$, and oxygen-derived free radicals. ${ }^{34}$

\section{Hydrocephalus}

CSF is produced in the choroid plexus in the lateral ventricles and flows through the third and fourth ventricles into the SAS and is finally absorbed by the arachnoid villi in the venous sinuses. In the setting of bacterial meningitis, the CSF outflow is impaired due to collection of exudative material in the SAS and blockage of arachnoid granulations, causing a communicating hydrocephalus. Animal studies have shown that when compared with controls, the maximal resistance to CSF outflow is markedly increased in acute pneumococcal meningitis, and similar observations, although to a lesser extent, have been reported when animals are infected with $E$. coli meningitis. ${ }^{24,42}$ The accumulation of fibrin, leukocytes, and eosinophilic debris in the subendothelial space along with the reduction in arachnoid vesicular transport is largely responsible for impairment of the valve-like absorptive mechanism of the arachnoid villi. It has also been shown that the impairment persists despite sterilization of CSF with antibiotics because of possible persistence of hydrocephalus-induced changes in the brain tissue and fibrosis in the SAS. ${ }^{42} \mathrm{Al}-$ though viral meningitis is not typically associated with acute hydrocephalus, animal studies revealed that viral pathogens selectively target ependymal and meningeal cells that can eventually lead to aqueductal stenosis later in the natural history of the disease. ${ }^{16}$ Further studies are required to ascertain the disease processes involved in adult viral meningitis.

\section{Clinical Relevance}

Elevated ICP has been established as a poor prognostic factor in all neurological diseases and is the main focus of treatment in various neurological emergencies. The data highlighting the significance of ICP monitoring in the treatment of meningitis is limited to case reports and to nonrandomized studies. The most likely reason is that the majority of patients are managed in nonneurointensive care units, where the focus is systemic resuscitation rather than cerebral resuscitation. Elevated ICP is a major and common complication of meningitis irrespective of 


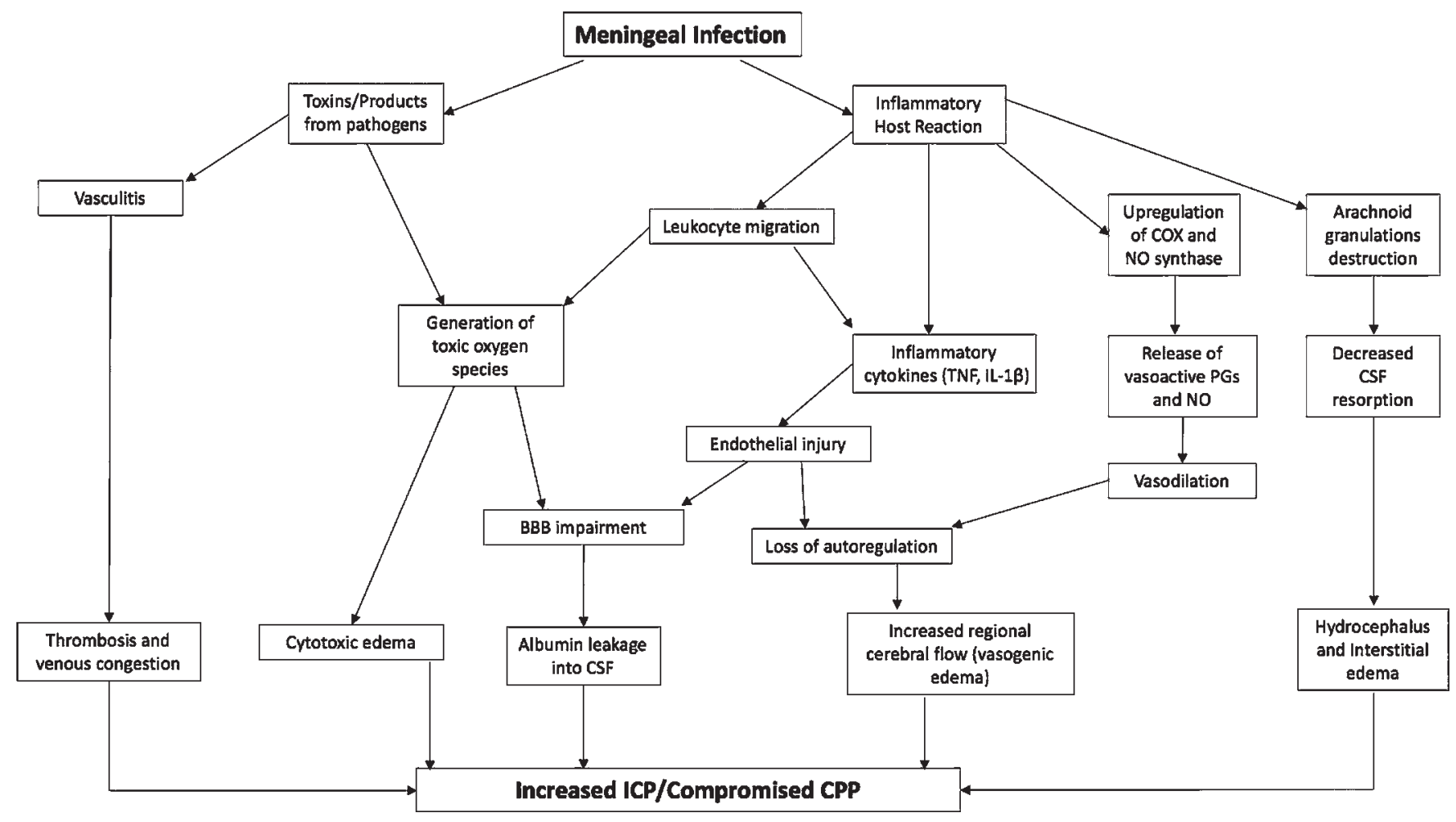

FIG. 1. Overview of the pathophysiology of meningitis-associated intracranial hypertension. Toxin-mediated injury and inflammatory host reaction in response to meningeal pathogens result in a series of changes (often overlapping) to disrupt the BBB, loss of autoregulation, and CSF outflow. Thrombosis and venous congestion secondary to infectious vasculitis may contribute toward raised ICP.

the offending pathogen. ${ }^{12,13}$ For instance, when defining intracranial hypertension as ICP $\geq 15 \mathrm{~mm} \mathrm{Hg}$, Rebaud et al. observed that $86 \%$ of the patients with acute viral meningoencephalitis suffered intracranial hypertension. ${ }^{39} \mathrm{In}$ another study, the incidence reported was higher among patients with severe bacterial meningitis (GCS score $\leq 8$ ), wherein $93 \%$ of patients admitted to the neurointensive care unit developed intracranial hypertension. ${ }^{21}$ Intracranial hypertension is not only limited to bacterial and viral infections, but also to parasitic and fungal pathogens, ${ }^{4,8,29,49}$ e.g., Cryptococcus is particularly notorious for causing intractable ICP requiring CSF drainage. . $^{8,23}$

Head CT is recommended in adults with suspected meningitis who present with focal neurological deficit or a decreased level of consciousness. However, many health care practitioners fail to realize that a head CT scan is insufficient to rule out elevated ICP. The failure to visualize brain edema on a CT scan in patients with meningitis has been reported in various studies..$^{15,21,41,53}$ Recently, a Danish study reported clinical outcomes in 39 patients with severe bacterial meningitis (GCS score $<9$ ) who received ICP monitoring, and the authors found no correlation between signs of elevated ICP on CT scans and ICP measurements, suggesting that ICP monitoring should be considered in all patients with severe meningitis regardless of CT findings. ${ }^{20}$ Furthermore, ophthalmoscopy is not a reliable method to detect acute increases in ICP because papilledema requires several days to develop and is usually present when the ICP is greater than $20 \mathrm{~mm} \mathrm{Hg}$. With a normal CT scan, physicians may be falsely reassured to proceed with a lumbar puncture that would otherwise be contraindicated in the setting of an abnormal CT scan or elevated ICP. The implications of performing a lumbar puncture in this situation could be detrimental. In a series of 445 patients, brain herniation occurred in 19 patients (4.3\%) with normal CT scans following lumbar puncture. Some of the episodes of herniation occurred as early as 3 hours after lumbar puncture. ${ }^{41}$ In another study, lumbar puncture precipitated brain herniation in patients with elevated ICP minutes after the procedure. ${ }^{15}$ Therefore, it can be argued that clinical signs of intracranial hypertension, especially in stuporous or comatose patients, should take precedence over CT findings in the immediate decision to initiate invasive ICP monitoring. ${ }^{22,53}$ In addition, patients presenting with a GCS score $\leq 8$ have significantly higher mortality rates compared with patients with a GCS score $\geq 12$, which is consistent with the fact that elevated ICP is more prevalent among patients with a lower GCS score. . $^{11,25,32,44,52}$

ICP may vary considerably through the course of the disease and regular ICP monitoring in select cases has been linked to improved outcomes. In a recent retrospective study in Europe, Depreitere et al. evaluated clinical outcomes in 17 patients with severe bacterial meningitis whose ICP was monitored. ${ }^{9}$ They found a significant correlation with the Glasgow Outcome Scale (GOS) score based on the highest documented ICP $(r=-0.70, p<0.01)$, the lowest documented CPP $(r=0.61,<0.05)$, pupil re- 


\section{A. Tariq et al.}

activity before drain placement $(\mathrm{r}=0.57, \mathrm{p}<0.05)$, and the number of episodes when CPP was $<50 \mathrm{~mm} \mathrm{Hg}$ ( $\mathrm{r}=$ $-0.50, \mathrm{p}<0.05)$. Interestingly, the treatment decision was affected by ICP monitoring in all cases. These results con- firmed that elevated ICP and low CPP are brain insults in the setting of bacterial meningitis and that ICP monitoring should be an adjunctive tool in the management of these patients. In a cohort of 15 patients in Sweden, Lindvall et

TABLE 1. Summary of literature review

\begin{tabular}{|c|c|c|c|c|c|}
\hline Study & Study Design & No. of Patients & Etiology & $\begin{array}{l}\text { ICP Monitoring/ } \\
\text { CSF Drainage }\end{array}$ & Results/Conclusions \\
\hline $\begin{array}{l}\text { Abulhasan et } \\
\text { al., } 2013\end{array}$ & $\begin{array}{l}\text { Retrospective } \\
\text { cohort }\end{array}$ & 37 & Bacterial meningitis & LD in 11 patients & $\begin{array}{l}\text { Mortality in LD } 0 \% \text { vs non-LD } 15.4 \%(p=0.0001) \\
\text { improved GOS score at } 3 \text { mos in LD (OR 1.49, } \\
95 \% \mathrm{Cl} 1.06-2.1, p=0.007)\end{array}$ \\
\hline $\begin{array}{r}\text { Baussart et } \\
\text { al., } 2006\end{array}$ & Case report & 1 & Neisseria meningitidis & ICP monitor & $\begin{array}{l}\text { GOS score of } 3 \text { at discharge, GOS score of } 4 \text { at } \\
6 \text { mos }\end{array}$ \\
\hline $\begin{array}{l}\text { Bordes et al., } \\
\quad 2010\end{array}$ & Case report & 1 & Type A Streptococcus & ICP monitor & GOS score $4-5$ at discharge $\& 12$ mos \\
\hline $\begin{array}{l}\text { Depreitere et } \\
\text { al., } 2016\end{array}$ & $\begin{array}{l}\text { Retrospective } \\
\text { cohort }\end{array}$ & 17 & Bacterial meningitis & ICP/CPP monitoring & $\begin{array}{l}\text { Decision management was affected in all patients; } \\
\text { GOS score was significantly \& negatively as- } \\
\text { sociated w/ the highest documented ICP }(r= \\
-0.70, p<0.01) \& \text { positively associated } w / \text { the } \\
\text { lowest documented CPP }(r=0.61, p<0.05)\end{array}$ \\
\hline $\begin{array}{l}\text { Di Rienzo et } \\
\quad \text { al., } 2008\end{array}$ & Case series & 3 & $\begin{array}{l}\text { Meningoencephalitis; } \\
\text { Patient 1: HSV, } \\
\text { Patients } 2 \text { \& } 3: \text { S. } \\
\text { pneumoniae }\end{array}$ & ICP monitor & $\begin{array}{l}\text { Patient 1: GOS score } 4-5 \text { at discharge; Patient } \\
\text { 2: GOS score } 1 \text { after surgery; Patient 3: GOS } \\
\text { score } 4-5 \text { at } 1 \text { mo }\end{array}$ \\
\hline $\begin{array}{l}\text { Gliemroth et } \\
\text { al., } 2002\end{array}$ & Case report & 1 & Meningoencephalitis & ICP monitor & GOS score $4-5$ at 1 yr after discharge \\
\hline $\begin{array}{l}\text { Glimåker et } \\
\text { al., } 2014\end{array}$ & $\begin{array}{l}\text { Prospective } \\
\text { interven- } \\
\text { tion-control } \\
\text { comparison }\end{array}$ & $\begin{array}{l}\text { 105: intervention } \\
52, \text { control } 53\end{array}$ & Bacterial meningitis & $\begin{array}{l}\text { Intervention group: } \\
\text { GCS score } \leq 9 \\
\text { CT scan, EVD } n= \\
\text { 48/52, ICP monitor } \\
n=4 / 52\end{array}$ & $\begin{array}{l}\text { Mortality in intervention group } 10 \% \text { vs } 30 \% \text { in } \\
\text { controls (RRR } 68 \%, p<0.05 \text { ); GOS score } 5 \text {, } \\
54 \% \text { intervention group \& } 32 \% \text { in controls (RRR } \\
\text { of unfavorable outcomes } 40 \%, p<0.05 \text { ) }\end{array}$ \\
\hline $\begin{array}{l}\text { Grände et } \\
\text { al., } 2002\end{array}$ & $\begin{array}{l}\text { Interventional } \\
\text { study }\end{array}$ & 12 & Bacterial meningitis & ICP monitor & $\begin{array}{l}\text { At 2-yr follow-up, complete recovery in } 7 \text { patients, } \\
\text { GOS score 3-4 in } 3 \text { patients, death in } 2 \\
\text { patients }\end{array}$ \\
\hline $\begin{array}{l}\text { Kumar et al., } \\
2014\end{array}$ & $\begin{array}{l}\text { Randomized } \\
\text { controlled } \\
\text { trial }\end{array}$ & $\begin{array}{l}\text { ICP-targeted } \\
\text { therapy group } \\
\text { 55, CPP- } \\
\text { targeted therapy } \\
\quad \text { group } 55\end{array}$ & $\begin{array}{l}\text { Multiple pathogens } \\
\text { (bacterial, viral, } \\
\text { aseptic, fungal) }\end{array}$ & ICP monitor & $\begin{array}{l}\text { 90-day mortality in ICP group was higher than } \\
\text { CPP group ( } 38.2 \% \text { vs } 18.2 \% \text {; RR } 2.1,95 \% \mathrm{Cl} \\
1.09-4.04, p=0.02 \text { ) }\end{array}$ \\
\hline $\begin{array}{l}\text { Larsen et al., } \\
2017\end{array}$ & $\begin{array}{l}\text { Retrospective } \\
\text { cohort }\end{array}$ & 39 & Bacterial meningitis & ICP/CPP monitoring & $\begin{array}{l}\text { Overall mortality rate was } 33 \%(13 / 39) \text { \& neurolog- } \\
\text { ical impairment in surviving patients was } 84.6 \% \\
(22 / 26) \text {; lower mean CPP was found to correlate } \\
\text { w/ adverse outcome ( } p=0.005) \text {; increased } \\
\text { ICP (>20 mm Hg) was found in } 24 \text { patients; no } \\
\text { significant correlation btwn measured ICP \& CT } \\
\text { scans w/ signs of elevated ICP }\end{array}$ \\
\hline $\begin{array}{l}\text { Lindvall et } \\
\text { al., } 2004\end{array}$ & $\begin{array}{l}\text { Interventional } \\
\text { study }\end{array}$ & 15 & Bacterial meningitis & $\begin{array}{l}\text { ICP monitor in } 14 / 15 \\
\text { EVD in } 1 / 15\end{array}$ & $\begin{array}{l}\text { Mortality in } 5 / 15 \text {, mean ICP was higher \& CPP } \\
\text { lower in nonsurvivors }\end{array}$ \\
\hline $\begin{array}{l}\text { Macsween et } \\
\text { al., } 2005\end{array}$ & Case report & 1 & $\begin{array}{l}\text { Cryptococcal men- } \\
\text { ingitis }\end{array}$ & LD & $\begin{array}{l}\text { Complete recovery \& no neurological deficits at } \\
\text { 1-yr follow-up }\end{array}$ \\
\hline $\begin{array}{l}\text { Perin et al., } \\
2008\end{array}$ & Case report & 1 & S. pneumoniae & EVD & $\begin{array}{l}\text { Fully independent at 33-day follow-up but com- } \\
\text { plete bilat hearing loss }\end{array}$ \\
\hline $\begin{array}{l}\text { Pili-Floury et } \\
\text { al., } 2009\end{array}$ & Case report & 1 & Herpetic encephalitis & ICP monitor & Complete recovery at 7-8-mo follow-up \\
\hline $\begin{array}{l}\text { Sparing et } \\
\text { al., } 2004\end{array}$ & Case report & 1 & $\begin{array}{l}\text { Mycoplasma pneu- } \\
\text { moniae }\end{array}$ & $\begin{array}{l}\text { ICP monitor, EVD s/p } \\
\text { surgery }\end{array}$ & $\begin{array}{l}\text { GOS score } 5 \text { at } 3 \text { mos \& eventual return to em- } \\
\text { ployment in subsequent follow-up visit }\end{array}$ \\
\hline
\end{tabular}

$E V D=$ extraventricular drainage; $H S V=$ herpes simplex virus; $L D=$ lumbar drainage; $R R R=R R$ reduction; $s / p=$ status post. 
al. reported significantly higher ICP among patients who died. ${ }^{21}$ Another study showed similar improved outcomes by implementing ICP-targeted treatment in patients managed in a neurocritical care setting..$^{15}$ These findings established the basis for a larger intervention control study, wherein the authors compared 52 patients subjected to ICP-targeted treatment to 53 control cases treated with conventional intensive care. ${ }^{13}$ These investigators showed that neurointensive treatment targeting ICP reduced the mortality rate at 2 months in the intervention group (10\%) compared with the control group (30\%), with a relative risk (RR) reduction of $68 \%(p<0.05)$. Furthermore, the recovery in terms of GOS score and hearing ability were noticed in the intervention group with a $40 \%$ RR reduction of unfavorable outcomes $(\mathrm{p}<0.05)$ on follow-up at 2 and 6 months. ${ }^{13}$ Similarly, another group showed that early use of CSF diversion by means of a lumbar drain led to improved results. ${ }^{1}$ The use of invasive monitoring has previously been shown to be safe in the pediatric population with meningitis ${ }^{28}$ and is considered a safe practice in other neurological emergencies in adult patients. Although parenchymal monitors are more popular, plausible results can be anticipated with early use of external ventricular drains, which allow both continuous ICP monitoring and ease of immediate CSF evacuation in susceptible patients. The premise is that CSF diversion reduced excitotoxic elements and free radicals in the infected CSF and controlled ICP.

As previously discussed, the pathophysiology of intracranial hypertension in meningitis is complex and multifactorial. Inflammation, cerebral edema, and impaired cerebral autoregulation are all implicated in the disease pathogenesis. Multimodal monitors may be indicated to evaluate the neuronal metabolism to achieve adequate control. ${ }^{12}$ For instance, Bordes et al. reported a case in which the craniectomy was guided by multimodal monitoring in a patient with elevated ICP whose CPP was maintained above $60 \mathrm{~mm} \mathrm{Hg}$, but microdialysis values were consistently abnormal, indicating metabolic crisis. ${ }^{3}$ Similar cases have been reported in which the surgical decision has been accelerated by an accurate ICP evaluation based on multimodal cerebral monitoring. ${ }^{2,10,45}$ Optimizing ICP alone may not be sufficient to improve the clinical outcome, as demonstrated in a recent clinical trial comparing ICP-targeted therapy $(<20 \mathrm{~mm} \mathrm{Hg})$ to CPP-targeted therapy $(\geq 60 \mathrm{~mm} \mathrm{Hg})$ in pediatric patients with acute CNS infections. ${ }^{19}$ The CPP-targeted therapy was associated with a lower mortality rate at 90-day postdischarge (primary outcome) compared with the ICP-alone strategy (18.2\% vs $38.2 \%$; RR 2.1, 95\% confidence interval [CI] 1.09-4.04, p $=0.02$ ). These results are consistent with those published by Odetola et al., who evaluated the use of ICP monitoring in a pediatric population with meningitis across the United States and found no statistical association with mortality rate. ${ }^{28}$ Similar findings were reported by Wall et al. in a recent Cochrane-based systematic review, which recommends against the use of osmotic diuretics in the treatment of bacterial meningitis. ${ }^{50}$ Wall et al. found no significant differences for benefit regarding death (RR 1.09, 95\% CI $0.89-1.33$ ) or death and neurological disability combined (RR 1.04, 95\% CI 0.86-1.25). Even though there is no consensus on the ICP-targeted therapy, an ICP monitor is fundamental to corroborate the presence of elevated ICP and calculate the CPP.

A summary of relevant studies/cases reporting ICP monitoring as part of the management of infectious meningitis can be found in Table 1. A proposed flowchart model based on our literature review and management protocols at our institution is included for the triage of patients with meningitis and suspected intracranial hypertension (Fig. 2).

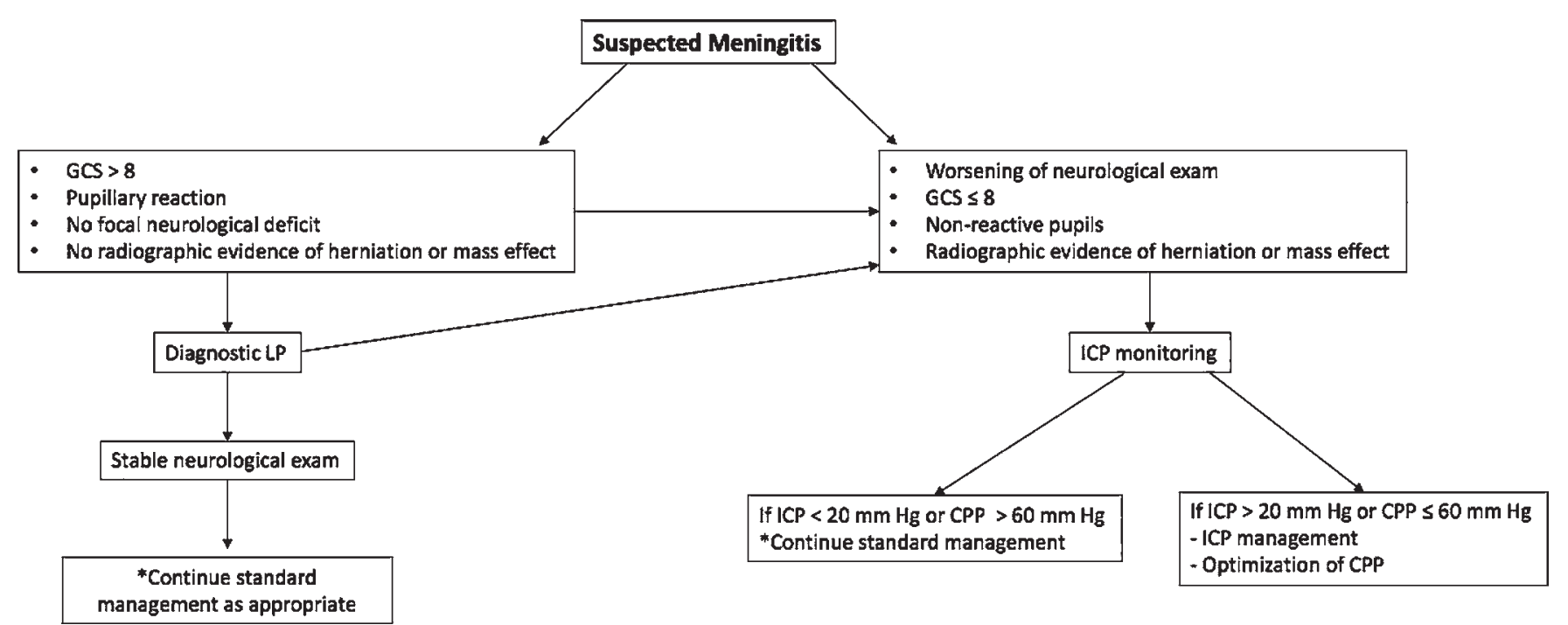

FIG. 2. Proposed flowchart for the use of ICP monitoring in patients with suspected intracranial hypertension associated with meningitis. In patients with deteriorating neurological examination, the decision to initiate ICP monitoring should take precedence over absent radiological evidence of increased ICP. *Management should be individualized, and overall it consists of hospitalization in the critical care unit and use of appropriate antimicrobial therapy. LP = lumbar puncture. 


\section{Conclusions}

Meningitis is a serious infection that continues to be associated with a high mortality rate despite advancement of medical care and the administration of effective antibiotics. Improved outcomes in patients with meningitis cannot be merely expected from administering new antimicrobial agents but through improvements of other aspects of general medical management. We emphasize the need for robust studies addressing timely investigation and early initiation of ICP monitoring among patients with meningitis. Although clear indications for the timing of ICP monitoring and specific treatment thresholds for ICP are poorly defined, a high level of clinical suspicion must be heeded concerning CT scan findings in the decision-making process for invasive ICP monitoring. In addition, use of a CSF monitor as well as drainage (lumbar or ventricular) have been linked to markedly improved outcomes in several case series. In summary, the current body of knowledge is inconsistent with the management of meningitis, and there is no clear agreement among providers advocating for the placement of ICP monitors. The purpose of this review was to convey the significance of an ICP monitor to allow optimization of ICP and CPP. However, further investigation is required to determine the target therapy goals in addition to antibacterial therapy to improve neurological outcomes. We are currently planning a prospective study at our institution to compare the efficacy of different ICPtargeted treatment protocols.

\section{References}

1. Abulhasan YB, Al-Jehani H, Valiquette MA, McManus A, Dolan-Cake M, Ayoub O, et al: Lumbar drainage for the treatment of severe bacterial meningitis. Neurocrit Care 19:199-205, 2013

2. Baussart B, Cheisson G, Compain M, Leblanc PE, Tadie M, Benhamou D, et al: Multimodal cerebral monitoring and decompressive surgery for the treatment of severe bacterial meningitis with increased intracranial pressure. Acta Anaesthesiol Scand 50:762-765, 2006

3. Bordes J, Boret H, Lacroix G, Prunet B, Meaudre E, Kaiser E: Decompressive craniectomy guided by cerebral microdialysis and brain tissue oxygenation in a patient with meningitis. Acta Anaesthesiol Scand 55:130-133, 2011

4. Bromilow J, Corcoran T: Cryptococcus gattii infection causing fulminant intracranial hypertension. Br J Anaesth 99:528-531, 2007

5. Carney N, Totten AM, O'Reilly C, Ullman JS, Hawryluk $\mathrm{GW}$, Bell MJ, et al: Guidelines for the management of severe traumatic brain injury, fourth edition. Neurosurgery 80:615,2017

6. Cuthbertson BH, Dickson R, Mackenzie A: Intracranial pressure measurement, induced hypothermia and barbiturate coma in meningitis associated with intractable raised intracranial pressure. Anaesthesia 59:908-911, 2004

7. Dagdemir A, Tasdemir HA, Dilber C, Gok F, Kubar A: Increased intracranial pressure due to chronic active EpsteinBarr virus infection. Pediatr Neurol 35:352-355, 2006

8. de Vedia L, Arechavala A, Calderón MI, Maiolo E, Rodríguez A, Lista N, et al: Relevance of intracranial hypertension control in the management of Cryptococcus neoformans meningitis related to AIDS. Infection 41:1073-1077, 2013

9. Depreitere B, Bruyninckx D, Güiza F: Monitoring of intracranial pressure in meningitis. Acta Neurochir Suppl 122:101-104, 2016
10. Di Rienzo A, Iacoangeli M, Rychlicki F, Veccia S, Scerrati M: Decompressive craniectomy for medically refractory intracranial hypertension due to meningoencephalitis: report of three patients. Acta Neurochir (Wien) 150:1057-1065, 2008

11. Durand ML, Calderwood SB, Weber DJ, Miller SI, Southwick FS, Caviness VS Jr, et al: Acute bacterial meningitis in adults. A review of 493 episodes. N Engl J Med 328:21-28, 1993

12. Gliemroth J, Bahlmann L, Klaus S, Klöhn A, Arnold H: Long-time microdialysis in a patient with meningoencephalitis. Clin Neurol Neurosurg 105:27-31, 2002

13. Glimåker M, Johansson B, Halldorsdottir H, Wanecek M, Elmi-Terander A, Ghatan PH, et al: Neuro-intensive treatment targeting intracranial hypertension improves outcome in severe bacterial meningitis: an intervention-control study. PLoS One 9:e91976, 2014

14. Goh KJ, Tan CT, Chew NK, Tan PS, Kamarulzaman A, Sarji SA, et al: Clinical features of Nipah virus encephalitis among pig farmers in Malaysia. N Engl J Med 342:1229-1235, 2000

15. Grände PO, Myhre EB, Nordström CH, Schliamser S: Treatment of intracranial hypertension and aspects on lumbar dural puncture in severe bacterial meningitis. Acta Anaesthesiol Scand 46:264-270, 2002

16. Johnson RT: Hydrocephalus and viral infections. Dev Med Child Neurol 17:807-816, 1975

17. Koedel U, Scheld WM, Pfister HW: Pathogenesis and pathophysiology of pneumococcal meningitis. Lancet Infect Dis 2:721-736, 2002

18. Kumar G, Kalita J, Misra UK: Raised intracranial pressure in acute viral encephalitis. Clin Neurol Neurosurg 111:399406, 2009

19. Kumar R, Singhi S, Singhi P, Jayashree M, Bansal A, Bhatti A: Randomized controlled trial comparing cerebral perfusion pressure-targeted therapy versus intracranial pressure-targeted therapy for raised intracranial pressure due to acute CNS infections in children. Crit Care Med 42:1775-1787, 2014

20. Larsen L, Poulsen FR, Nielsen TH, Nordström CH, Schulz MK, Andersen AB: Use of intracranial pressure monitoring in bacterial meningitis: a 10 -year follow up on outcome and intracranial pressure versus head CT scans. Infect Dis (Lond) 49:356-364, 2017

21. Lindvall P, Ahlm C, Ericsson M, Gothefors L, Naredi S, Koskinen LO: Reducing intracranial pressure may increase survival among patients with bacterial meningitis. Clin Infect Dis 38:384-390, 2004

22. Lyons MK, Meyer FB: Cerebrospinal fluid physiology and the management of increased intracranial pressure. Mayo Clin Proc 65:684-707, 1990

23. Macsween KF, Bicanic T, Brouwer AE, Marsh H, Macallan DC, Harrison TS: Lumbar drainage for control of raised cerebrospinal fluid pressure in cryptococcal meningitis: case report and review. J Infect 51:e221-e224, 2005

24. Mactier H, Galea P, McWilliam R: Acute obstructive hydrocephalus complicating bacterial meningitis in childhood. BMJ 316:1887-1889, 1998

25. Merkelbach S, Röhn S, König J, Müller M: Usefulness of clinical scores to predict outcome in bacterial meningitis. Infection 27:239-243, 1999

26. Mertineit C, Samlalsingh-Parker J, Glibetic M, Ricard G, Noya FJ, Aranda JV: Nitric oxide, prostaglandins, and impaired cerebral blood flow autoregulation in group B streptococcal neonatal meningitis. Can J Physiol Pharmacol 78:217-227, 2000

27. Møller K, Qvist T, Tofteng F, Sahl C, Sønderkaer S, Dethloff $\mathrm{T}$, et al: Cerebral blood flow and metabolism during infusion of norepinephrine and propofol in patients with bacterial meningitis. Stroke 35:1333-1339, 2004

28. Odetola FO, Tilford JM, Davis MM: Variation in the use of 
intracranial-pressure monitoring and mortality in critically ill children with meningitis in the United States. Pediatrics 117:1893-1900, 2006

29. Ozisik HI, Ersoy Y, Refik Tevfik M, Kizkin S, Ozcan C: Isolated intracranial hypertension: a rare presentation of neurobrucellosis. Microbes Infect 6:861-863, 2004

30. Pedersen M, Brandt CT, Knudsen GM, Østergaard C, Skinhøj $\mathrm{P}$, Frimodt-Møller N, et al: Cerebral blood flow autoregulation in early experimental S. pneumoniae meningitis. J Appl Physiol (1985) 102:72-78, 2007

31. Pedersen M, Brandt CT, Knudsen GM, Østergaard C, Skinh $\varnothing$ P, Skovsted IC, et al: The effect of S. pneumoniae bacteremia on cerebral blood flow autoregulation in rats. J Cereb Blood Flow Metab 28:126-134, 2008

32. Perin A, Nascimben E, Longatti P: Decompressive craniectomy in a case of intractable intracranial hypertension due to pneumococcal meningitis. Acta Neurochir (Wien) 150:837842,2008

33. Pfister HW, Feiden W, Einhäupl KM: Spectrum of complications during bacterial meningitis in adults. Results of a prospective clinical study. Arch Neurol 50:575-581, 1993

34. Pfister HW, Koedel U, Haberl RL, Dirnagl U, Feiden W, Ruckdeschel G, et al: Microvascular changes during the early phase of experimental bacterial meningitis. J Cereb Blood Flow Metab 10:914-922, 1990

35. Pili-Floury S, Valentin L, Blasco G, Godard J, Samain E: [Late refractory intracranial hypertension treated by decompressive craniectomy in severe herpetic encephalitis.] Ann Fr Anesth Reanim 28:709-710, 2009 (Fr)

36. Quagliarello V, Scheld WM: Bacterial meningitis: pathogenesis, pathophysiology, and progress. N Engl J Med 327:864872, 1992

37. Quagliarello VJ, Long WJ, Scheld WM: Morphologic alterations of the blood-brain barrier with experimental meningitis in the rat. Temporal sequence and role of encapsulation. $\mathbf{J}$ Clin Invest 77:1084-1095, 1986

38. Radetsky M: Fulminant bacterial meningitis. Pediatr Infect Dis J 33:204-207, 2014

39. Rebaud P, Berthier JC, Hartemann E, Floret D: Intracranial pressure in childhood central nervous system infections. Intensive Care Med 14:522-525, 1988

40. Reese TS, Karnovsky MJ: Fine structural localization of a blood-brain barrier to exogenous peroxidase. J Cell Biol 34:207-217, 1967

41. Rennick G, Shann F, de Campo J: Cerebral herniation during bacterial meningitis in children. BMJ 306:953-955, 1993

42. Scheld WM, Dacey RG, Winn HR, Welsh JE, Jane JA, Sande MA: Cerebrospinal fluid outflow resistance in rabbits with experimental meningitis. Alterations with penicillin and methylprednisolone. J Clin Invest 66:243-253, 1980

43. Scheld WM, Koedel U, Nathan B, Pfister HW: Pathophysiology of bacterial meningitis: mechanism(s) of neuronal injury. J Infect Dis 186 (Suppl 2):S225-S233, 2002

44. Schutte CM, van der Meyden CH: A prospective study of
Glasgow Coma Scale (GCS), age, CSF-neutrophil count, and CSF-protein and glucose levels as prognostic indicators in 100 adult patients with meningitis. J Infect 37:112-115, 1998

45. Sparing R, Spitzer C, Häfner H, Zolldann D, Reinges MH, Krings T, et al: [Fulminant meningoencephalitis associated with Mycoplasma pneumoniae infection in adults. Aggressive treatment enabled a good outcome.] Nervenarzt 75:10161021, 2004 (Ger)

46. Spence M: Severe intracranial infections. Int Anesthesiol Clin 17:285-305, 1979

47. Täuber MG: Brain edema, intracranial pressure and cerebral blood flow in bacterial meningitis. Pediatr Infect Dis J 8:915-917, 1989

48. Thigpen MC, Whitney CG, Messonnier NE, Zell ER, Lynfield R, Hadler JL, et al: Bacterial meningitis in the United States, 1998-2007. N Engl J Med 364:2016-2025, 2011

49. Tunkel AR, Scheld WM: Acute bacterial meningitis in adults. Curr Clin Top Infect Dis 16:215-239, 1996

50. Wall EC, Ajdukiewicz KM, Heyderman RS, Garner P: Osmotic therapies added to antibiotics for acute bacterial meningitis. Cochrane Database Syst Rev (3):CD008806, 2013

51. Weisfelt M, de Gans J, van der Poll T, van de Beek D: Pneumococcal meningitis in adults: new approaches to management and prevention. Lancet Neurol 5:332-342, 2006

52. Weisfelt M, van de Beek D, Spanjaard L, Reitsma JB, de Gans J: A risk score for unfavorable outcome in adults with bacterial meningitis. Ann Neurol 63:90-97, 2008

53. Winkler F, Kastenbauer S, Yousry TA, Maerz U, Pfister HW: Discrepancies between brain CT imaging and severely raised intracranial pressure proven by ventriculostomy in adults with pneumococcal meningitis. J Neurol 249:1292-1297, 2002

\section{Disclosures}

Dr. Hanel is a consultant for Medtronic, Stryker, Codman, and MicroVention; owns stock in Blockade, Neurvana, and Inneuroco; and serves on the scientific advisory board of Medina Medical.

\section{Author Contributions}

Conception and design: all authors. Acquisition of data: Chmayssani, Tariq, Aguilar-Salinas. Analysis and interpretation of data: all authors. Drafting the article: all authors. Critically revising the article: all authors. Reviewed submitted version of manuscript: all authors. Approved the final version of the manuscript on behalf of all authors: Chmayssani. Administrative/technical/material support: all authors. Study supervision: all authors.

\section{Correspondence}

Mohamad Chmayssani, Lyerly Neurosurgery, Baptist Neurological Institute, 800 Prudential Dr., Ste. 1100, Jacksonville, FL 32207. email: mohamad.chmayssani@bmcjax.com. 